\title{
Abbreviations Used in the Footnotes
}

The most important documentary material used in this study is drawn from the four so-called "negotiating volumes" of The Pentagon Papers (U.S. Department of Defense, U.S.-Vietnam Relations, 1945-1967 [Washington, D.C.: U.S. Government Printing Office, 1971], VI. C. 1-4). Because those volumes were the last to be compiled and were thus put together hastily, they present serious problems for the analyst attempting to identify his sources carefully and completely. Each volume is divided into numerous sections and subsections, often with separate pagination for each subsection. As a result, establishing the exact location of a cable or memo cited in those volumes requires the identification of both the volume and the section (or subsection) in which the item appears. Without the use of some system of abbreviations, providing full citations for each cable or memo drawn from the "negotiating volumes" would have made the footnotes prohibitively long; but since the "negotiating volumes" contain several dozen subsections, the following list of abbreviations is provided as an aid for those readers who wish to follow the notes closely:

Sections and
Volume
Subsections

VI. Settlement of the The Seaborn Mission Conflict

C. History of Contacts

1. Negotiations, 1965-1966 to Hanoi, June 1964June 1965

Discussion

Summary

Chronology

Project MAY.

FLOWER-The First Bombing Pause
Abbreviations Used in the Notes
Seaborn Discussion

Seaborn Summary Seaborn Chronology

(not cited-duplicates material in the Gravel edition of The Pentagon Papers [see below]) 


\begin{tabular}{|c|c|c|}
\hline \multirow[t]{7}{*}{ Volume } & $\begin{array}{l}\text { Sections and } \\
\text { Subsections }\end{array}$ & $\begin{array}{l}\text { Abbreviations Used } \\
\text { in the Notes }\end{array}$ \\
\hline & $\begin{array}{l}\text { XYZ (Mai Van Bo } \\
\text { Contacts), May 1965- } \\
\text { February } 1966\end{array}$ & \\
\hline & $\begin{array}{l}\text { Summary and } \\
\text { Analysis } \\
\text { Chronology }\end{array}$ & $\begin{array}{l}\text { XYZ Summary and } \\
\text { Analysis } \\
\text { XYZ Chronology }\end{array}$ \\
\hline & $\begin{array}{l}\text { Pinta: The Rangoon } \\
\text { Contact }\end{array}$ & \\
\hline & $\begin{array}{l}\text { Summary and } \\
\text { Analysis } \\
\text { Principal Events } \\
\text { in the Rangoon } \\
\text { Contact }\end{array}$ & $\begin{array}{l}\text { Pinta Summary and } \\
\text { Analysis } \\
\text { (not cited) }\end{array}$ \\
\hline & $\begin{array}{l}\text { The Ronning Mis- } \\
\text { sions: March and June } \\
1966\end{array}$ & Finta Cnronology \\
\hline & $\begin{array}{l}\text { Summary and } \\
\text { Analysis } \\
\text { Chronology }\end{array}$ & $\begin{array}{l}\text { Ronning Summary } \\
\text { and Analysis } \\
\text { Ronning Chronology }\end{array}$ \\
\hline $\begin{array}{l}\text { ment of the } \\
\text { lict }\end{array}$ & Summary & (not cited) \\
\hline $\begin{array}{l}y \text { of } \\
\text { cts }\end{array}$ & Discussion & Marigold Discussion \\
\hline old & Chronology & Marigold Chronology \\
\hline $\begin{array}{l}\text { lement of the } \\
\text { aflict } \\
\text { ory of }\end{array}$ & $\begin{array}{l}\text { Principal Dates } \\
\text { During Sunflower }\end{array}$ & (not cited) \\
\hline acts & $\begin{array}{l}\text { Discussion } \\
\text { Chronology }\end{array}$ & $\begin{array}{l}\text { Sunflower Discussion } \\
\text { Sunflower Chronology }\end{array}$ \\
\hline $\begin{array}{l}\text { tlement of the } \\
\text { nflict }\end{array}$ & The Setting & The Setting \\
\hline $\begin{array}{l}\text { tory of } \\
\text { htacts } \\
\text { otiations, }\end{array}$ & $\begin{array}{l}\text { The U.S. and DRV } \\
\text { Conditions for "Talks" } \\
\text { Converge }\end{array}$ & Conditions for Talks \\
\hline & Settlement Terms & Settlement Terms \\
\hline
\end{tabular}




\begin{tabular}{|c|c|c|}
\hline \multirow[t]{8}{*}{ Volume } & $\begin{array}{l}\text { Sections and } \\
\text { Subsections }\end{array}$ & $\begin{array}{l}\text { Abbreviations Used } \\
\text { in the Notes }\end{array}$ \\
\hline & $\begin{array}{l}\text { Settlement Terms- } \\
\text { Extracts }\end{array}$ & $\begin{array}{l}\text { Settlement Terms- } \\
\text { Extracts }\end{array}$ \\
\hline & $\begin{array}{l}\text { Aspen [The Swedish } \\
\text { Channel] }\end{array}$ & Aspen \\
\hline & $\begin{array}{l}\text { Pennsylvania [Aubrac- } \\
\text { Marcovich] }\end{array}$ & Pennsylvania \\
\hline & $\begin{array}{l}\text { Rumanian-North } \\
\text { Vietnamese Contacts, } \\
\text { October 1966- } \\
\text { November } 1967\end{array}$ & $\begin{array}{l}\text { Rumanian } \\
\text { Chronology }\end{array}$ \\
\hline & $\begin{array}{l}\text { Packers (Rumanian- } \\
\text { NVN Track): } \\
\text { November 1967- } \\
\text { February } 1968\end{array}$ & Packers \\
\hline & $\begin{array}{l}\text { Killy: Italian-North } \\
\text { Vietnamese Track, } \\
\text { February-March } 1968\end{array}$ & Killy \\
\hline & $\begin{array}{l}\text { Ohio [Norwegian } \\
\text { Channel] }\end{array}$ & Ohio \\
\hline
\end{tabular}

Because of the large number of books and articles cited in this study, the full citation for each is given the first time each appears; thereafter, sources are identified only by the last name of the author(s) (in the case of multiple works by the same author, the date of publication is included to identify the specific work being cited). A complete list of the books and articles cited in the notes can be found in the bibliography.

In addition, the following abbreviations are used in the notes:

Full Citation

"Experiences of the South Vietnamese Revo- The CRIMP Document lutionary Movement During the Past Several Years"; a history of the Viet Cong movement written by a Communist cadre sometime around 1963; captured by U.S. troops in South Vietnam during Operation CRIMP in January 1966 
Full Citation

Abbreviation

Department of State Bulletin

DOSB

Courtroom transcript of U.S. us. Ellsberg and Ellsberg Trial Transcript Russo, U.S. District Court, Los Angeles, 1971

Foreign Broadcast Information Service

FBIS

The Pentagon Papers, The Senator Gravel

Edition, 5 volumes (Boston: Beacon Press, 1971)

Public Papers of the President: Lyndon B. Johnson Papers

Johnson (published annually)

National Security Study Memorandum No. 1, NSSM-1

1969 (an interagency study of U.S. options in the Vietnam conflict, commissioned by President Nixon for his use in reviewing U.S. policy toward the war)

U.S. Department of Defense, U.S.-Vietnam U.S.-Vietnam Relations Relations, 1945-1967 (Washington, D.C.:

U.S. Government Printing Office, 1971) (the official U.S. Government edition of The Pentagon Papers)

U.S. Department of State, "Working Paper Working Paper on the North Vietnamese Role in the War in South Vietnam," reprinted in Vietnam Documents and Research Notes, no. 37, May 1968 